\title{
PEMBERDAYAAN MASYARAKAT MELALUI PENGEMBANGAN AGROWISATA BERKONSEP GREEN MARKETING (ORGANIK) DI KECAMATAN LICIN
}

\author{
Galih Satriyo $^{1}$, Suwarso ${ }^{2}$, Fandi Ahmad ${ }^{3}$, Saiful Rohman ${ }^{4}$ \\ ${ }^{1}$ Dosen Akademi Kelautan Banyuwangi, \\ g.satriyoakaba@gmail.com
}

\section{Abstract}

The geographical condition of the Banyuwangi district $5,782.50 \mathrm{~km} 2$ is partly a forest area. One element of the agricultural sector that has not been explored optimally is agro-tourism. The physical potential of the Banjar and Segobang Villages has volcanic and Alluvial types which are very fertile because they are located on the slopes of Mount Ijen. The purpose of this research is to encourage the people of Segobang Village and Banjar Village, Licin District to optimize their agricultural land so that they have added value by realizing agro-tourism through community empowerment. The method in this study uses qualitative methods. The results of this study are that farmers need guidance to manage agricultural businesses into tourism businesses, so it is not only limited to how to meet food needs. Village parties need to promote through social / web media, print media and festivals. The potential of each village needs to be combined with branding, Segobang Village with "MINA UMBAR" branding and Banjar Village with "JEMALI" Licin Sweet Orange Branding. Building a network between farmers and several resorts and homestays around the villages of Banjar and Segobang also needs to be done with the aim of good fish, organic rice, palm sugar and slippery oranges can be used as souvenirs and food and beverage menu items.

Keywords: : Community Empowerment, Agro Tourism, Green Marketing.

\section{Pendahuluan}

Pertanian merupakan roda penggerak ekonomi nasional. Presiden Republik Indonesia Bapak Joko Widodo melalui Nawa Citanya mengarahkan pembangunan pertanian ke depan untuk mewujudkan kedaulatan pangan. Kedaulatan pangan melalui swasembada pangan tersebut diartikan mencukupi kebutuhan pangan dari produksi dalam negeri, mengatur kebijakan pangan secara mandiri, serta melindungi dan menyejahterakan petani sebagai pelaku utama usaha pertanian pangan. 
Kondisi geografi kabupaten Banyuwangi 5.782,50, dengan persawahan sekitar 66.152 ha atau $11,44 \%$, perkebunan dengan luas sekitar $82.143,63$ ha atau 14,21\%. Daratan yang datar sebagian besar mempunyai tingkat kemiringan kurang dari $15^{\circ}$, dengan rata-rata curah hujan cukup memadai sehingga bisa menambah tingkat kesuburan tanah. Paradigma pariwisata mulai beralih ke konsep eco-tourism atau ekowisata.Salah satu unsur dari sektor pertanian yang saat ini belum tergarap secara optimal adalah agro wisata (agro tourism).

RPJMD Kabupaten Banyuwangi 2016-2021, bahwa tema dan prioritas pembangunan tahun 2019 ditekankan pada pemantaban kontribusi sektor pertanian dan pariwisata terhadap perekonomian regional dan pemerataan pendapatan masyarakat dengan prioritas pendukung strategi pembangunan melalui pengembangan dan penguatan pasar untuk produk pertanian yang integrative dengan pariwisata, penguatan produktifitas pertanian dan produk olahan turunan, pengembangan dan pemasaran produk unggulan kabupaten, pengembangan pelaku usaha berbasis pemberdayaan masyarakat desa dan membangun keterpaduan antar wilayah untuk pengembangan pariwisata dan pertanian.

Tabel 1. Data wisatawan di Kabupaten Banyuwangi Tahun 2014-2018

\begin{tabular}{crccccc}
\hline No & Indikator & $\mathbf{2 0 1 4}$ & $\mathbf{2 0 1 5}$ & $\mathbf{2 0 1 6}$ & $\mathbf{2 0 1 7}$ & $\mathbf{2 0 1 8}$ \\
\hline 1 & $\begin{array}{l}\text { Kunjungan wisata } \\
\text { Domestik }\end{array}$ & $1,363,530$ & $1,727,958$ & $4,022,449$ & $4,832,999$ & $5,200,000$ \\
2 & $\begin{array}{l}\text { Kunjungan wisata } \\
\text { Mancanegara }\end{array}$ & 30,068 & 45,569 & 77,139 & 98,970 & 127,420 \\
\hline
\end{tabular}

Sumber (Banyuwangikab.go.id)

Jumlah kunjungan wisatawan di Kabupaten Banyuwangi yang terus meningkat setiap tahunnya serta potensi geografis Kecamatan Licin yang letaknya di ketinggian $>230$ yang beriklim sejuk dengan hasil produktivitas pertaniannya merata disetiap Desanya. Sehingga sangat disayangkan bila potensi pertanian di Licin tidak dimanfaatkan secara optimal.

Inovasi agro wisata dapat dilakukan dengan mina padi dan mina holtikultura untuk menambah penghasilan petani, yaitu dapat panen pertanian sekaligus panen ikan. Di sektor hortikultura perlu dilakukan pengembangan pada berbagai komoditas, seperti tanaman buah (frutikultura), tanaman sayur (olerikultura), tanaman bunga (florikultura), tanaman obat (biofarmaka) dengan konsep organik.

Desa Segobang, tanahnya mempunyai jenis Vulkanis dan Alluvial yang sangat subur karena letaknya di daerah lereng Pegunugan Ijen dan dekat dengan daerah Hujan Tropic. Potensi air sangat melimpah karena banyaknya sumber air dan sungai-sungai serta udara yang masih sejuk dan segar karena lingkungan yang hijau. Hasil pertanian sejak dahulu yang sudah dikenal adalah padi,buah-buahan misalnya durian,manggis, pisang, langsat,kepundung dan lain-lain. Segobang juga dikenal sebagai penghasil gula lirang atau gula aren.

Areal persawahan terasiring yang ada di Desa Banjar dinilai mirip seperti Ubud di Bali, sehingga menjadi daya tarik wisata tersendiri bertajuk Taman Langit. Selain itu beberapa warga memiliki usaha pembuatan oleh-oleh khas desa seperti Sego lemeng, Gula aren, Kopi uthek.

Minat berkunjung para wisata baik dari dalam negeri maupun luar negeri pada Taman Wisata Alam Gunung Ijen semakin meningkat setiap tahunnya. sehingga sudah banyak berdiri penginapan atau villa, kuliner dan resort. 
Berdasarkan latar belakang masalah maka dapat dirumuskan masalah dalam penelitian ini adalah

1. Bagaimana kondisi eksisting agrowisata melalui pemanfaatan lahan pertanian untuk pemberdayaan masyarakat Licin ?

2. Faktor-faktor apa yang dapat mendukung perkembangan agrowisata melalui pemanfaatan lahan pertanian untuk pemberdayaan masyarakat Licin?

Tujuan penelitian ini adalah untuk mendorong masyarakat Desa Segobang dan Desa Banjar, Kecamatan Licin untuk mengoptimalkan lahan pertaniannya agar memiliki nilai tambah dengan mewujudkan agrowisata melalui pemberdayaan masyarakat.

\section{Kerangka Teoritis}

\section{Definisi Pariwisata}

Undang-undang No. 10 Tahun 2009 tentang Kepariwisataan mendefinisikan wisata sebagai kegiatan perjalanan yang dilakukan seseorang atau sekelompok orang dengan mengunjungi tempat tertentu untuk tujuan rekreasi, pengembangan pribadi, atau mempelajari keunikan daya tarik wisata yang dikunjungi dalam jangka waktu sementara.

Pariwisata adalah pergerakan manusia yang bersifat sementara ke tujuan-tujuan wisata yang berada diluar tempat kerja dan tempat tinggalnya sehari-hari dimana aktivitas dilaksanakan selama tinggal dalam daerah tujuan wisata dan disediakannya fasilitas-fasilitas untuk memenuhi kebutuhan mereka (Mathieson and Wall, 1982 dalam Bharuna 2009).

\section{Jenis-jenis Wisata}

Berdasarkan Mieczkowski (1995 : 459), Pariwisata dibedakan menjadi dua macam, yakni : Mass Tourism dan Alternative Tourism. Mass tourism bersifat konvensional, standar dan berskala besar. Alternative tourism terdiri dari 5 (lima) macam yakni : cultural tourism (pariwisata budaya), Educational tourism (pariwisata pendidikan), scientific tourism (pariwisata science), adventure tourism (pariwisata petualangan) dan agritourism ( pariwisata pertanian) yang kesemuanya merupakan Nature Tourism atau Ecotourism (pariwisata berwawasan lingkungan).

Menurut Suwardjoko P. Warpani dan Indira Warpani (2007:13-15) batasan pariwisata sangat luas dan sesuai dengan maksud berwisata atau kegiatan yang dilakukan oleh wisatawan, maka pariwisata di kategorikan menjadi:

\section{Wisata agro}

Kegiatan pariwisata ini dikaitkan dengan kegiatan industri pertanian, misalnya wisata durian pada saat musim buah durian, atau wisata tani, yakni para wisatawan ikut turun aktif menanam padi dan memandikan kerbau di sungai.

2. Wisata belanja

Kegiatan pariwisata yang dilakukan karena kekhasan barang yang ditawarkan, misalnya Sidoarjo dengan pusat tas di Tanggulangin.

3. Wisata budaya

Wisatawan melakukannya dengan maksud mengadakan riset budaya, mempelajari budaya setempat, mengunjungi situs bersejarah, dan sebagainya. 
4. Wisata iklim

Kunjungan ke suatu tempat berkaitan dengan maksud mencari perubahan iklim setempat, misalnya bagi negara beriklim empat pada saat tertentu benar-benar dimanfaatkan untuk melakukan perjalanan mengunjungi tempat-tempat lain hanya untuk berburu panas sinar matahari, penduduk pantai berwisata ke pegunungan, penduduk pedalaman berwisata ke pantai.

5. Wisata karya

Para wisatawan berkunjung dengan maksud dinas atau tugas lain, namun dalam waktu senggang mereka melakukan kunjungan wisata. 10

6. Wisata kesehatan

Wisatawan mengunjungi suatu tempat karena keberadaan penyembuhan, misalnya kunjungan ke Krakal di Kebumen dengan maksud berendam di air belerang untuk penyembuhan sakit kulit, berkunjung ke Singapura untuk berobat.

7. Wisata konvensi/seminar

Dengan sengajamemilih salah satu daerah tujuan wisata(DTW) sebagai tempat penyelenggaraan seminar dikaitkan dengan upaya pengembangan DTW yang bersangkutan.

8. Wisata niaga

Wisatawan datang karena ada urusan perniagaan di tempat tersebut, namun pada waktu luang pada umumnya berwisata.

9. Wisata olahraga

persahabatan. Yang termasuk para wisatawan yaitu para olahragawan, penonton, Pariwisata ini dilakukan dengan mengunjungi peristiwa penting di dunia olahraga, misalnya pertandingan perebutan kejuaraan, pekan olahraga nasional, atau sekedar pertandingan dan semua yang terlibat dalam peristiwa olahraga.

10. Wisata rekreasi

Kegiatan ini dilakukan untuk berlibur, mencari suasana baru, memuaskan rasa ingin tahu, melihat sesuatu yang baru, menikmati keindahan alam, yang dimaksudkan untuk memulihkan kesegaran dan kebugaran jasmani dan rohani setelah berwisata.

11. Wisata petualangan

Termasuk dalam jenis wisata petualangan adalah kegiatan pelatihan (kepemimpinan) di alam terbuka dengan berbagai atraksi yang menantang dan kadang-kadang mengandung resiko. Contohnya antara lain terbang layang, arung jeram, panjat tebing, menyelam, susur gua.

12. Wisata ziarah

Jenis pariwisata ini dilakukan dengan cara mengunjungi tempat ibadah atau tempat ziarah pada waktu tertentu, misalnya mengunjungi tempat yang dianggap keramat, ziarah ke makam tokoh-tokoh masyarakat atau pahlawan bangsa.

13. Darmawisata

Dilakukannya perjalanan beramai-ramai untuk bersenang-senang, atau berkaitan dengan pelaksanaan darma di ruangan, atau melakukan pengabdian kepada masyarakat di luar waktu kerja sehari-hari.

14. Widiawisata (pendidikan)

Jenis pariwisata ini dilakukan dalam rangka kunjungan studi, dilakukan untuk mempelajari seni budaya rakyat, mengunjungi dan meneliti cagar alam dan atau budaya. 


\section{Definisi Agrowisata}

Agrowisata merupakan bagian dari objek wisata yang memanfaatkan usaha pertanian sebagai objek wisata. Tujuannya adalah untuk memperluas pengetahuan, pengalaman rekreasi, dan hubungan usaha dibidang pertanian. Melalui pengembangan agrowisata yang menonjolkan budaya local dalam memanfaatkan lahan, pendapatan petani dapat meningkat bersamaan dengan upaya melestarikan sumberdaya lahan, serta memelihara budaya maupun teknologi local (indigenous knowledge) yang umumnya telah sesuai dengan kondisi lingkungan alaminya. (Gumelar S. Sastrayuda 2010:1)

Agrowisata merupakan terjemahan dari istilah bahasa Inggris agrotourism. Berdasarkan asal katanya, agro berarti pertanian dan tourism berarti pariwisata/kepariwisataan. Agrowisata atau agrotourism adalah berwisata ke daerah pertaniaan. Pertaniaan dalam arti luas mencakup pertaniaan rakyat perkebunan, kehutanan, peternakan, dan perikanan (Alikodra, 2012).

\section{Pemberdayaan masyarakat}

UU No. 6 Tahun 2015 tentang Desa menjelaskan bahwa: Pemberdayaan masyarakat desa adalah upaya mengembangkan kemandirian dan kesejahteraan masyarakat dengan meningkatkan pengetahuan, sikap, keterampilan, perilaku, kemampuan, kesadaran, serta memanfaatkan sumber daya melalui penetapan kebijakan, program, kegiatan, dan pendampingan yang sesuai dengan esensi masalah dan prioritas kebutuhan masyarakat Desa.

Oos M. Anwas (2013:49) "pemberdayaan adalah menyiapkan kepada masyarakat berupa sumber daya, kesempatan, pengetahuan dan keahlian untuk meningkatkan kapasitas diri masyarakat di dalam menentukan masa depan mereka, serta berpartisipasi dan mempengaruhi kehidupan dalam komunitas masyarakat itu sendiri"

\section{Bagan dan Road Map Penelitian}

Bagan Penelitian

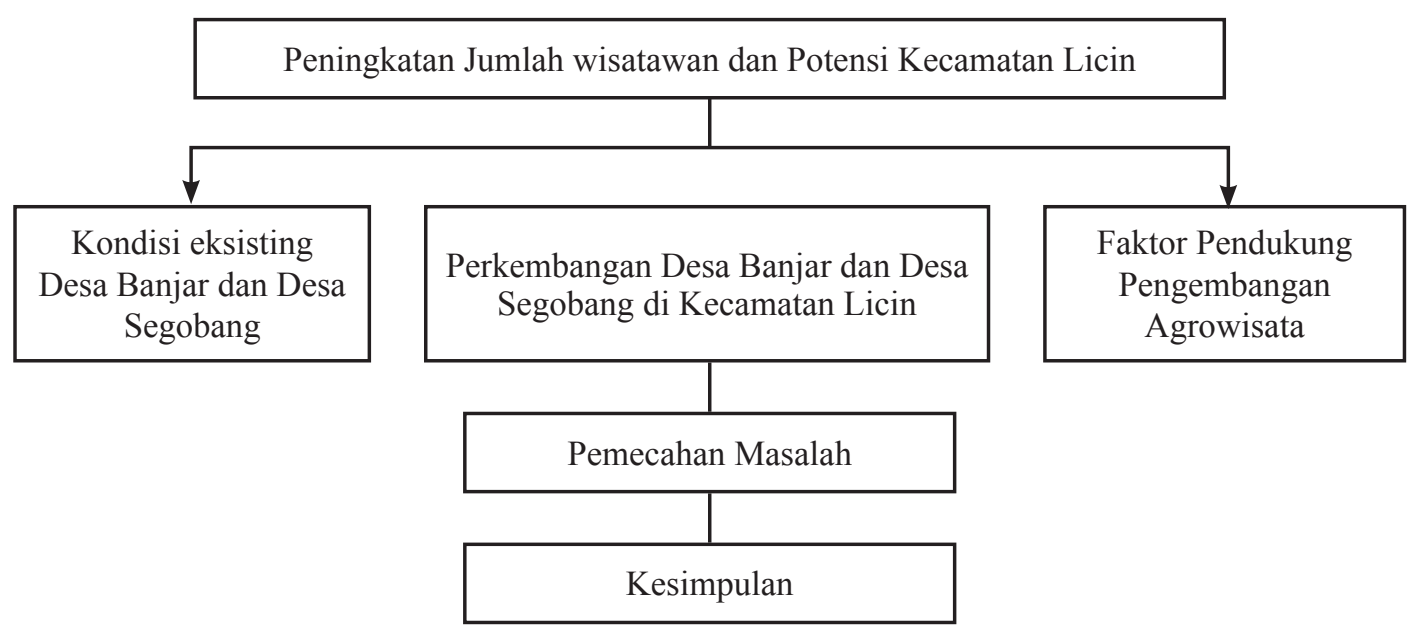

Gambar 1. Bagan Penelitian 


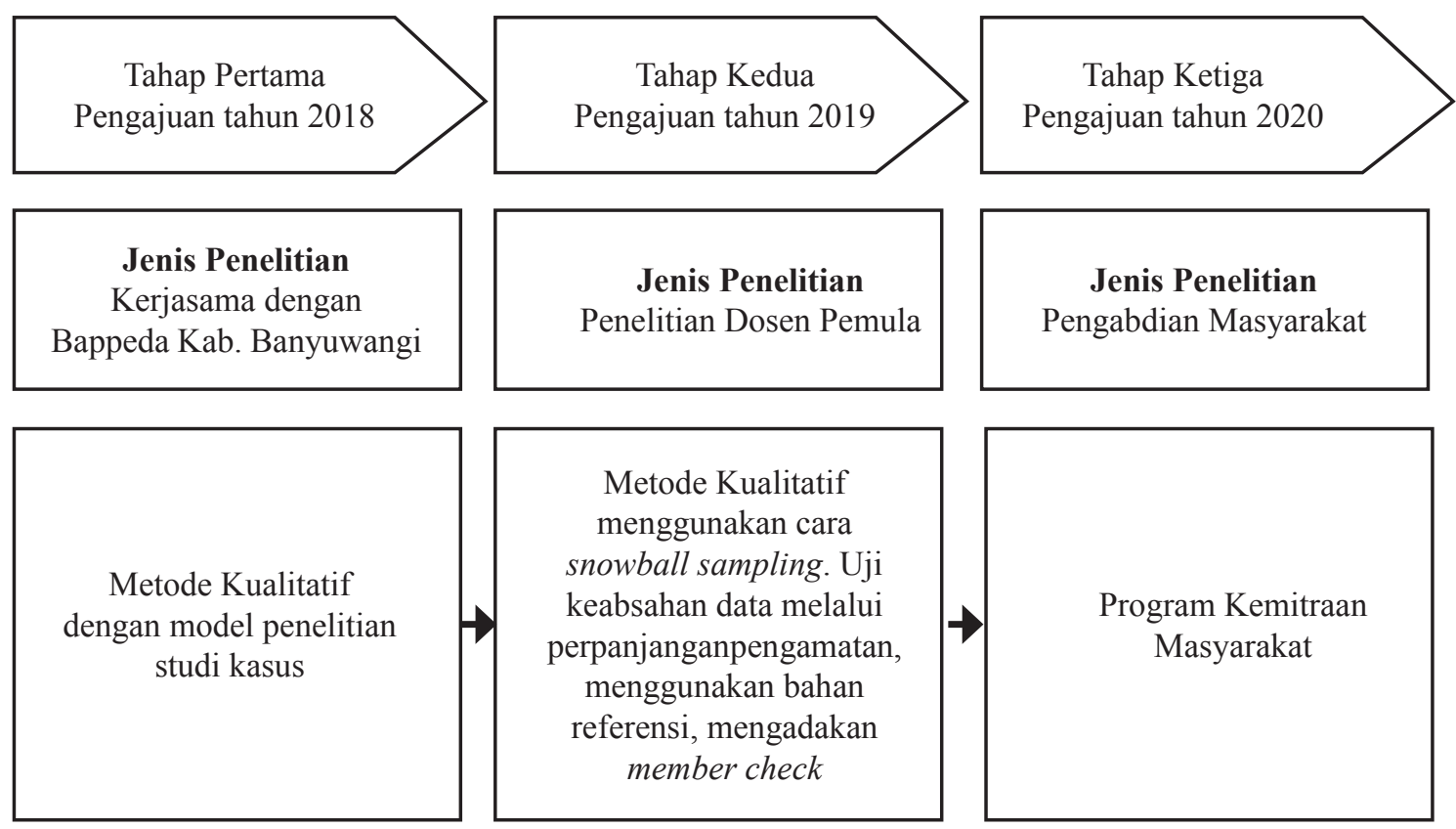

Gambar 2. Road Map Penelitian

\section{Metode Penelitian}

Metode dalam penelitian ini penggunakan metode kualitatif. Pengambilan sampel dalam penelitian ini direncanakan menggunaka purposive sampling yaitu dengan cara mengambil subjek bukan didasarkan atas strata, random atau daerah tetapi didasarkan atas adanya tujuan tertentu.Informan yang akan menjadi narasumber (key informan) dalam penelitian ini adalah Dinas Pertanian dan Dinas Pariwisata Kabupaten Banyuwangi, aparatur kecamatan, aparatur desa, gapoktan dan masyarakat setempat di Kecamatan Licin.

Pengumpulan data dilakukan dengan wawancara selanjutnya dianalisis dengan cara reduksi data, penyajian data dan kesimpulan sementara. Untuk menguji keabsahan data dilakukandengan perpanjangan pengamatan, meningkatkan ketekunan, analisis kasus negative, menggunakan bahan referensi dan mengadakan member check. Kemudian menarik kesimpulan dari analisis tersebut dan memberikan rekomendasi sesuai dengan kenyataan yang ada dilapangan.

\section{Hasil dan Pembahasan}

\section{Hasil}

Secara geografis Desa Banjar dan Desa Segobang bersebelahan dengan Gunung Ijen dengan ketinggian kurang lebih $500 \mathrm{~m}$ dan $600 \mathrm{~m}$ diatas permukaan laut. Suhu udara rata-rata setiap hari di Desa Banjar dan Desa Segobang berada pada kisaran $25-30^{\circ} \mathrm{C}$ dengan kelembaban $35 \%$. Selain buah jeruk, manggis dan durian, tanaman yang juga berjumlah banyak di desa ini adalah pohon aren. Dusun Rembang paling barat hampir seluruh warganya menanam buah jeruk, selain itu terdapat lahan Perhutani yang ditanami pinus. Sedangkan Desa Segobang sedang 
membudidayakan ikan tawar baik melalui areal persawahan juga di arealirigasi pengairan sawah yang berada di sekitar rumah warga.

\section{Pembahasan}

Untuk menjawab tujuan penelitian, peneliti menganalisis beberapa bidang indikator yaitu sumber daya manusia, promosi, sumber daya alam lingkungan, sarana prasarana dan kelembagaan. Penelitian ini menunjukkan bahwa :

a. Sisibidang Sumber Daya Manusia, Kepala Dusun bersama seluruh lapisan masyarakat berinisiatif mengemas dan menyajikan paket-paket wisata yang dapat memiliki nilai jual dari potensi desanya, walaupun belum dilakukan secara maksimal dan terorganisir. Sebagian petani berkenan selain mengelola lahan persawahannya juga digunakan sebagai media spot foto secara swadaya.
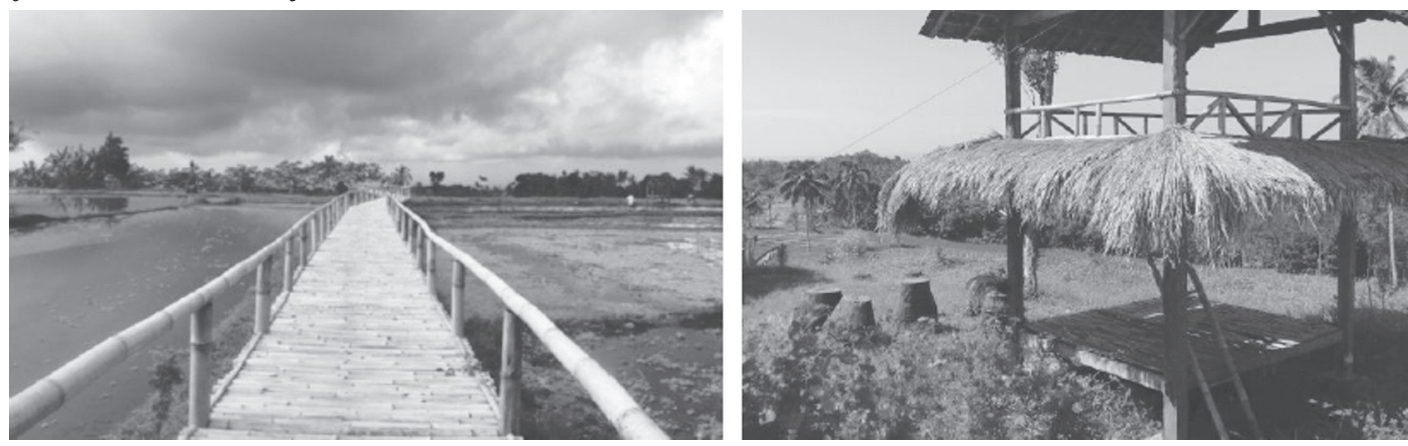

Gambar 3. Spotfoto di Desa Banjar (sumber : dokumentasi peneliti)

Selain bidang pertanian, masyarakat Desa Banjar juga berinisiatif membangun sanggar seni, souvenir dan membuat kerajinan batik serta kuliner dengan tujuan untuk menambah daya tarik wisatawan serta berdampak pada peningkatan perekonomian masyarakat melalui pemberdayaan masyarakat desa. Sebagian kecil petani Desa Banjar dan Desa Segobang sadar peran tanaman organik dan sudah ada yang mengolah tanaman padinya secara organik.
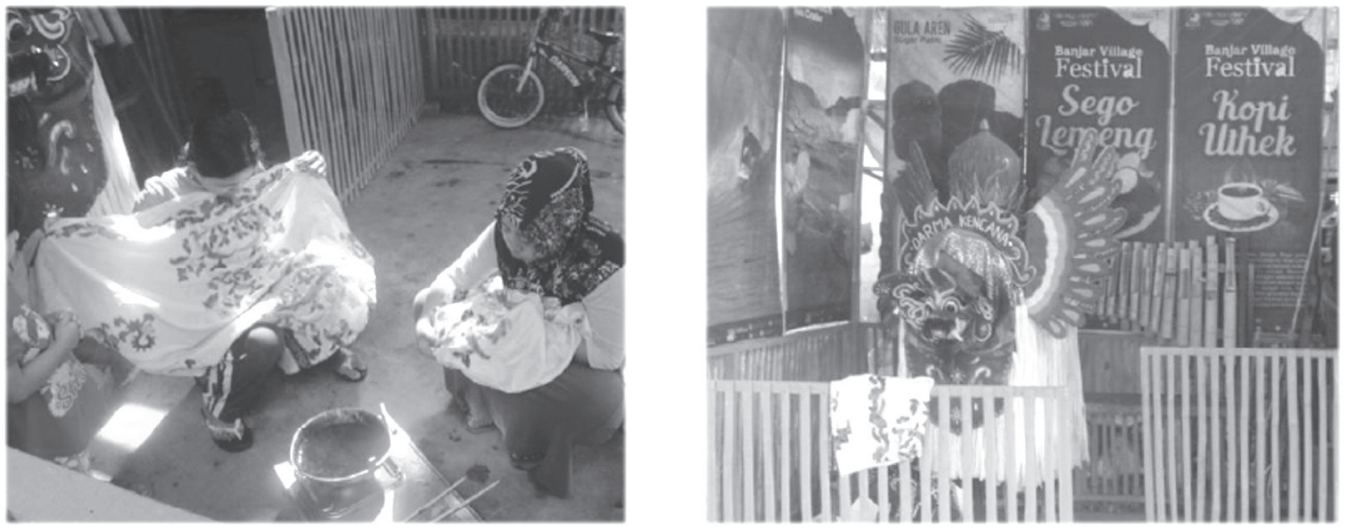

Gambar 4. Sanggar Seni (sumber : dokumentasi peneliti) 
b. Sisibidang promosi, kerjasama dengan jasa biro perjalanan maupun perhotelan atau homestay sekitar belum didukung media promosi yang tepat. Promosi melalui internet belum dilakukan sendiri oleh pihak Desa, melainkan dilakukan oleh pengunjung yang up load gambar atau video kegiatan wisata mereka. Promosi potensi Desa Banjar dan Desa Segobang belum secara optimal melibatkan jasa angkutan dari Pemerintah Daerah dengan program "ANGKUTAN WISATA GRATIS".

c. Sisi bidang Sumber Daya Alam dan Lingkungan, secara umum, ruang lingkup dan potensi agrowisata yang dapat dikembangkan di Desa Banjar dan Desa Segobang yaitu perkebunan, tanaman pangan dan hortikultura, dan perikanan. Tanaman buah khas Desa Licin adalah manggis dan durian. Lay out persawahan di Desa Banjar dan Desa Segobang rata-rata lay out nya terasiring.

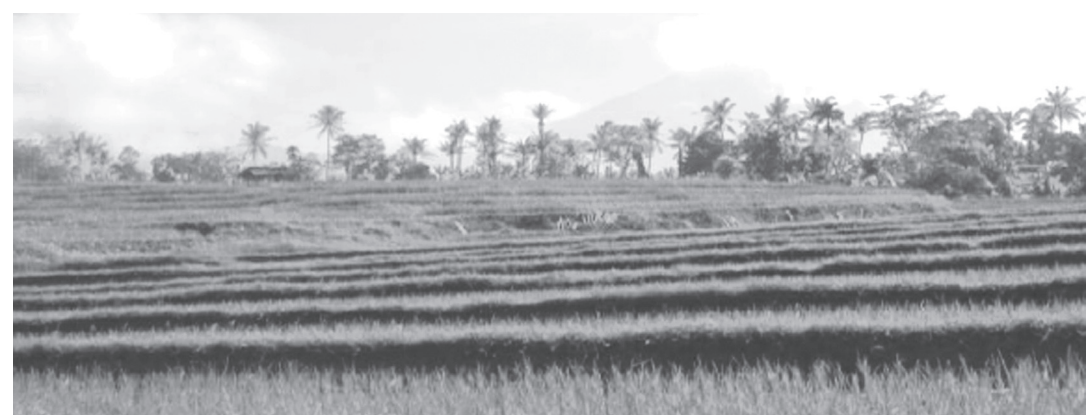

\section{Gambar 5. Layoutteras iring persawahan di Desa Banjar dan Desa Segobang}

(sumber : dokumentasi peneliti)

Pengolahan sawah dengan bajak tradisional menggunakanhewan dapat dimanfaatkan sebagai atraksi yang dapat ditunjukkan kepada para wisatawan asing. Desa Banjar memiliki varietas baru buah jeruk. Jeruk jemali tersebut bisa dikatakan sebagai branding atau icon dari Desa Banjar dengan jenis yang belum ada pada umumnya serta buahnya tidak terikat musim panen dan rasanya pernah menjuarai tingkat Jawa Timur. Selain buah tersebut Desa Banjar dan Desa Segobang terkenal penghasil buah aren. Bahkan gula merah aren Desa Segobang sudah tersertifikasi. Para Petani Desa Segobang menerapkan teknik perawatan ikan dengan sebutan "MINA UMBAR" yaitu teknik merawat ikan dengan cara mengumbar ikan di sawah sambil menunggu masa tanam tiba. Praktis teknik tersebut dapat digunakan sebagai branding atau icon Desa Segobang sebagai Desa Ikan "MINA UMBAR”.
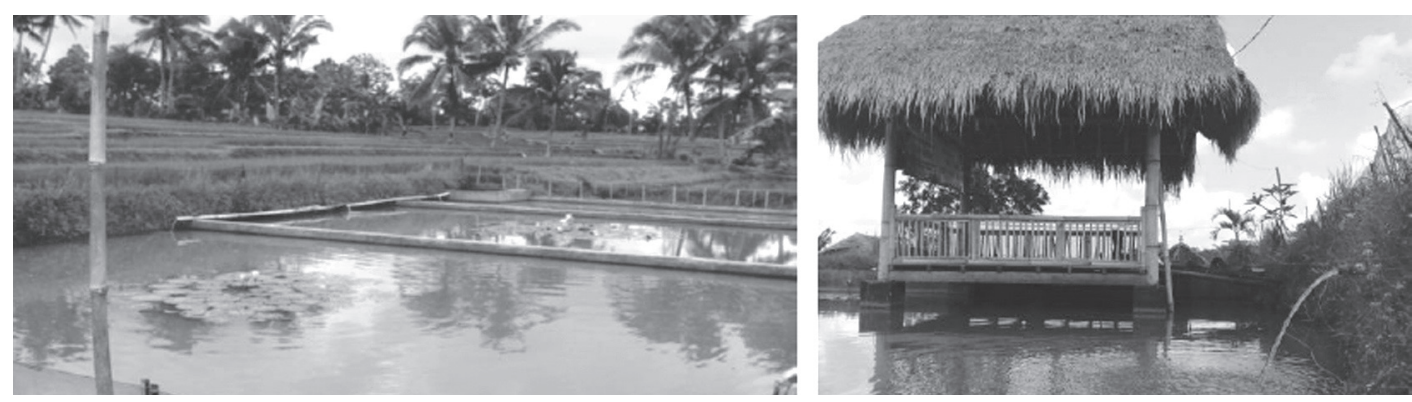

Gambar 6. Mina Umbar di persawahan Desa Segobang (sumber : dokumentasi peneliti) 
d. Sisi bidang sarana dan prasarana, akses jalan Kabupaten menuju Desa Banjar dan Desa Segobang yang bagus dengan nuansa alam persawahan yang asri dan iklim sejuk disepanjang perjalanan serta telah didukung dengan sarana akomodasi yang cukup memadai disekitar Desa Segobang dan Desa Banjar berupa villa maupun homestay.

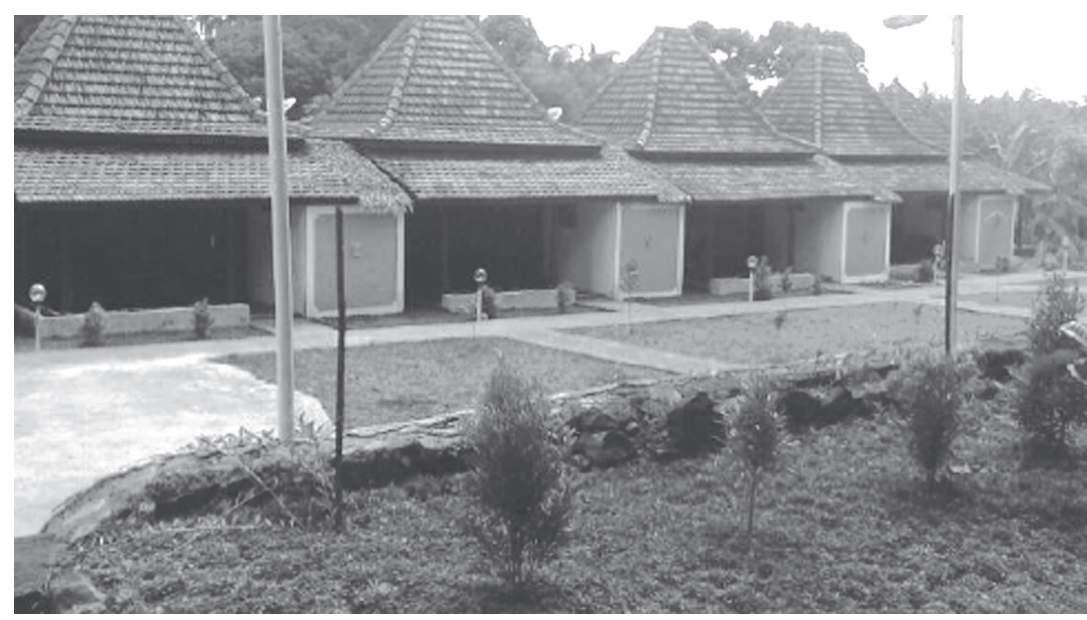

\section{Gambar 7. Homestay di Desa Banjar (sumber : dokumentasi peneliti)}

e. Sisi bidang kelembagaan, Pemerintah Daerah melalui Dinas Kebudayaan dan Pariwisata turut serta mempromosikan setiap desa yang bersedia mengeksplore potensi alam dan adat istiadat masyarakatnya. Pemerintah Daerah juga rutin melakukan festival setiap tahunnya baik bidang agama, olahraga, agrowisata, seni dan adat istiadat dengan lokasi tersebar dibeberapa kecamatan serta Desa di Kabupaten Banyuwangi. Pada prinsipnya semua lembaga seperti Dinas Pertanian, Dinas Pariwisata serta pemerintah desa setempat memberikan dukungan penuh untuk pengembangan agrowisata di Kecamatan Licin.

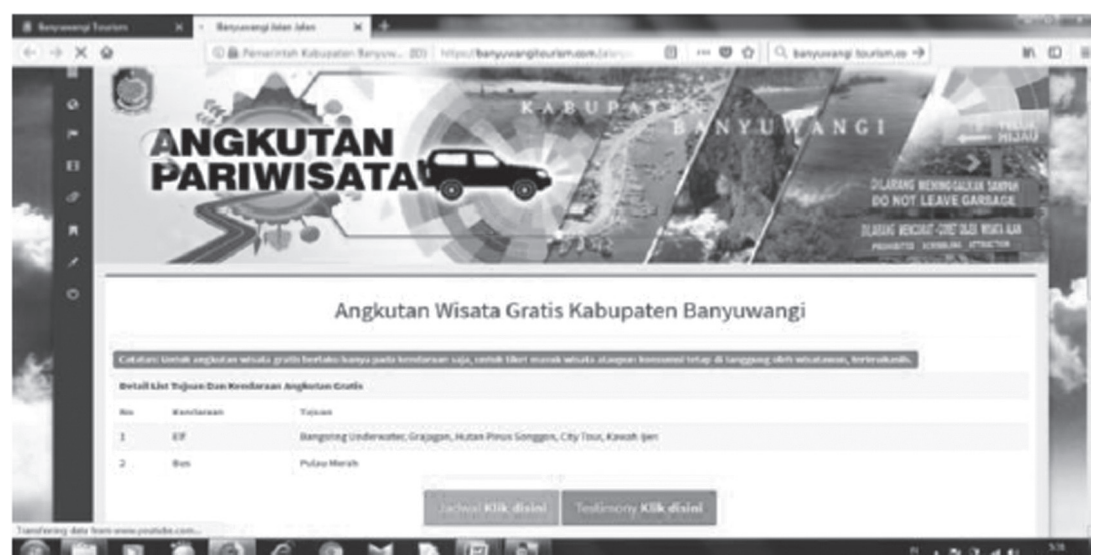

Gambar 8. Web angkutan wisata gratis Kab. Banyuwangi

(sumber: https://banyuwangitourism.com) 


\section{Simpulan dan Saran}

\section{Simpulan}

Berdasarkan analisis yang telah dilakukan, maka dapat diberi kesimpulan sebagai berikut:

Aparat desa bersama sebagian masyarakat berinisiatif mengemas dan menyajikan paketpaket wisata yang dapat memiliki nilai jual dari potensi desanya, baik secara swadaya maupun menggunakan dana desa. Namun belum dilakukan secara terorganisir dan masih otodidak.

Media promosi belum dilakukan secara tepat oleh pihak desa saat melakukan kerjasama dengan jasa biro perjalanan maupun perhotelan atau homestay sekitar. Penyampaian informasi dan pesan promosi masih melalui cinderamata dan kuliner, dan masih dilakukan oleh pengunjung yang up load gambar atau video kegiatan wisata mereka. Memberikan leaflet dan booklet pada biro perjalanan, perhotelan dan jasa angkutan khususnya pada angkutan wisata gratis program Pemkab Banyuwangi. Promosi melalui media internet perlu dilakukan secara mandiri oleh Desa Segobang maupun Desa Banjar, sehingga gambaran potensi desa baik alam dan seni diketahui masyarakat secara utuh.

Secara umum, ruang lingkup dan potensi agrowisata yang dapat dikembangkan yaitu perkebunan, perikanan tanaman pangan dan hortikultura, dengan Lay out persawahan rata-rata teras iring. Mengolah sawah masih dilakukan secara tradisional dalam memulai masa tanam, hal tersebut dapat dimanfaatkan sebagai atraksi wisata. Licin terdapat banyak pohon aren, agrowisata buah yang dapat di jadikan branding atau icon di Desa Banjar adalah buah jeruk jemali karena merupakan jenis yang belum ada pada umumnya serta buahnya tidak terikat musim panen dan rasanya pernah menjuarai tingkat jawa timur dan di Desa Segobang adalah selain potensi persawahan layaknya ubud Bali dan buah durian. Desa Segobang memiliki "MINA UMBAR" yaitu teknik merawat ikan dengan cara mengumbar ikan di sawah sambil menunggu masa tanam tiba. Praktis teknik tersebut dapat digunakan sebagai branding atau icon Desa Segobang sebagai Desa Ikan "MINA UMBAR".

Akses jalan Kabupaten menuju Desa Banjar dan Desa Segobang yang bagus dengan nuansa alam persawahan yang asri dan iklim sejuk disepanjang perjalanan. Sarana akomodasi telah tersedia cukup memadai berupa rumah makan, maupun homestay.

Pemda Banyuwangi dan semua Instansi seperti Dinas Pertanian, Dinas Perikanan dan Dinas Pariwisata serta pemerintah desa setempat memberikan dukungan penuh untuk pengembangan agrowisata di Kecamatan Licin dengan catatan setiap desa bersedia mengeksplore potensi alam dan adat istiadat masyarakatnya.

\section{Saran}

Berdasarkan kesimpulan hasil penelitian berjudul Pemberdayaan Masyarakat Melalui Pengembangan Agrowisata Berkonsep Green Marketing di Kecamatan Licin, maka rekomendasi yang dapat kami berikan adalah sebagai berikut:

\section{Pemerintah Daerah Kabupaten Banyuwangi}

1. Pemerintah daerah secara selektif terkait penetapan dana desa (DD), Adanya porsi yang berbeda antara desa yang wisata desanya sudah maju dengan wisata desanya yang belum maju sebagai stimulus desa yang masih tertinggal untuk mengoptimalkan potensi wisata desanya, mengingat objek wisata alam merupakan investasi jangka panjang. 
2. Merekomendasikan kepada instansi-instansi tentang pelaksanaan acara-acara semisal pelatihan maupun rapat yang biasanya diselenggarakan di hotel maupun gedung pemerintah di pusat kota dialihkan ke desa-desa sekitar kota sekaligus melakukan wisata iklim dan wisata konvensi atau seminar.

3. Pemda memfasilitasi ke pihak hotel di pusat kota untuk mempromosikan potensi setiap desa di Banyuwangi.

\section{Pemerintah Desa Banjar dan Desa Segobang}

1. Pemerintah desa secara intens untuk memotivasi masyarakatnya membentuk Kelompok Sadar Wisata (Pokdarwis)

2. Pemerintah desa setempat merancang program kegiatan wisata alam desa dengan melibatkan masyarakat, seperti memancing, memberi pakan dan menangkap ikan; menanam padi dan membuat gula aren; membajak sawah; petik buah

3. Pemerintah desa bersama masyarakat setempat membentuk branding atau icon dalam memanfaatkan potensi desanya dan sebagai ciri khas dari desa. Misal Desa Segobang "MINA UMBAR" dan Desa Banjar "PETIK JERUK JEMALI"

4. Pemerintah desa berkoordinasi dengan Pemerintah daerah untuk memanfaatkan program pemerintah "Angkutan Wisata Gratis" dalam mempromosikan desanya

5. Pemerintah desa lebih aktif mempromosikan potensi agrowisata, baik melalui media online, leaflet, booklet, pameran, cinderamata, serta penyediaan informasi pada agen perjalanan, tempat public (hotel, restoran, bandara dan lainnya) maupun festival local maupun daerah

6. Menambah atraksi wisata serta penyesuaian jadwal atraksi atau festival seni antar desa dan pemerintah daerah serta agent tour travel sehingga itinerary wisatawan menjadi berkelanjutan, guna memperpanjang masa menginap wisatawan khusunya wisatawan asing.

\section{Masyarakat}

1. Mengaktifkan kembali kegiatan yang bersifat tradisional baik seni, adat istiadat dan kegiatan harian seperti membajak sawah dan memasak menggunakan media tanah liat (luweng)

2. Gapoktan Dusun Rembang koordinasi dengan dinas pertanian untuk menyuburkan kembali jeruk disekitar daerah Rembang

3. Aktif dalam perencanaan dan pengelolaan eksplorasi potensi alam desa dengan mengadopsi agroexpo yang diselenggarakan pemerintah daerah Banyuwangi dengan menambah keindahan menggunakan ornamen hiasan-hiasan melalui bahan yang disediakan alam, misal bambu dan bunga refugia

4. Memasarkan hasil-hasil panen baik ikan, beras organik, gula merah aren dan jeruk khas licin ke resort dan homestay sekitar desa sebagai buah tangan dan bahan menu makanan maupun minuman.

\section{Agen Travel}

1. Turut mempromosikan potensi desa yang masih taraf mengembangkan wisatanya

2. Meminta tanggapan wisatawan domistik maupun mancanegara mengenai pengelolaan wisata alam pedesaan dan menyampaikannya ke pemerintah desa.

\section{Perguruan Tinggi}

Turut serta aktif melalui kegiatan penelitian dan pengabdian masyarakat untuk ikut membantu mengembangkan kegiatan wisata desa sebagai bagian Tri Dharma Perguruan Tinggi 


\section{Peneliti yang lain}

Melakukan penelitian mengenai pengembangan pariwisata yang lebih mendalam dengan kategori pariwisata yang lain, misal widiawisata atau pendidikan maupun wisata religi

\section{Daftar Pustaka}

Alikodra, H.A. 2012. Konservasi Sumberdaya Alam dan Lingkungan. ed. Efransjah, Darusman, D. Yogyakarta. Gadjah Mada University Press

Anwas, M Oos. 2014.Pemberdayaan Masyarakat di Era Globalisasi. Bandung. Alfabata

Bharuna S, Anak Agung Gde Djaja. 2009. Pola Perencanaan Dan Strategi Pembangunan Wisata Alam Berkelanjutan Serta Berwawasan Lingkungan. Jurnal Bumi Lestari, Volume 9 No.1 : 121-128

Mieczkowski,Z.1995. Environmental Issues Of Tourism and Recreation. London. Univ.Press of America Inc.

Sastrayuda, Gumelar. 2010. Konsep Pengembangan Kawasan Ekowisata. Yogyakarta.

Sugiyono. 2012. Memahami Penelitian Kualitatif. Bandung : ALFABETA

Undang-undang No. 10 Tahun 2009 tentang Kepariwisataan

Undang-undang no. 6 Tahun 2015 tentang Desa

Warpani, Suwardjoko dan Indira Warpani, 2007. Pariwisata dalam Tata Ruang Wilayah. Bandung: ITB. 